\title{
$\$$ Research Square

\section{In vitro protocol for bud induction from adventitious roots of purple sweet potato (Ipomoea batatas (L.) Lam)}

Genhai Hu ( $\sim$ hgh1013@126.com )

Henan Institute of Science and Technology https://orcid.org/0000-0001-7896-422X

Maoni Chao

Henan Institute of Science and Technology

\section{Yuanzhi Fu}

Henan Institute of Science and Technology

\section{Xiaohong Zhang}

Henan Institute of Science and Technology

\section{Research Article}

Keywords: Purple sweet potato,Adventitious roots,Adventitious shoots,Plant regeneration, Acclimation of nutrient solution

Posted Date: February 11th, 2022

DOI: https://doi.org/10.21203/rs.3.rs-1308922/v1

License: (c) (i) This work is licensed under a Creative Commons Attribution 4.0 International License. Read Full License 
In vitro protocol for bud induction from adventitious roots of purple sweet potato (Ipomoea batatas (L.) Lam)

Genhai Hu·Maoni Chao $\cdot$ Yuanzhi Fu·Xiaohong Zhang

Collaborative Innovation Center of Modern Biological Breeding Henan Province, Henan Institute of Science and Technology, Hualan Road, Xinxiang 453003, Henan, China

\section{Abstract}

A new efficient in vitro plant regeneration system characterized by rapidly sequential organogenesis using leaf explants has been developed in sweet potato [Ipomoea batatas L. (Lam.)]. The optimal regeneration plant response was obtained in the varieties Ning Purple Potato No. 1 with a four-step protocol: The first stage was callus induction of leaf explants for 40 days on MS medium containing 2,4-dichlorophenoxyacetic acid (2,4-D) $\left(0.8 \mathrm{mg} \mathrm{L}^{-1}\right)$, the second stage was adventitious roots being induced from callus on solid MS medium with $0.6 \mathrm{mg} \mathrm{L}^{-1} 6-\mathrm{BA}$ and 0.3 $\mathrm{mg} \mathrm{L}^{-1} \mathrm{NAA}$, A different proportions combination of of 6-BA and NAA could induce adventitious roots. The third stage was adventitious buds being induced from adventitious roots, solid MS medium with $2.0 \mathrm{mg} \mathrm{L}^{-1} \mathrm{ZT}, 1.0 \mathrm{mg} \mathrm{L}^{-1} \mathrm{KT}$ and $1.0 \mathrm{mg} \mathrm{L}^{-1} \mathrm{GA}_{3}$ produce a maximum of number of adventitious shoots after 12 week. In the third stage the combination of hormones and the longer induction time was important. the fourth stage was acclimation of nutrient solution. The key of this method was that refining seedlings does not require humidity control and there is no need to pre-open the flask to acclimatize. We had developed an efficient protocol to generate plants. As the method is simple, rapid and consistently reproducible, it may be of value in germplasm maintenance and gene transfer studies.

\section{Key message}

The present study develops a protocol for bud induction from adventitious roots of purple sweet potato and a new method for domesticating regenerated seedlings by hydroponics.

\footnotetext{
${ }^{\square}$ Genhai Hu

hgh1013@126.com

Maoni Chao

chaomaoni@126.com

Yuanzhi Fu

lilac1210@126.com

Xiaohong Zhang

12-126meinv@163.com

Collaborative Innovation Center of Modern Biological

Breeding Henan Province, Henan Institute of Science and

Technology, Hualan Road, Xinxiang 453003, Henan, China
} 
Keywords Purple sweet potato-Adventitious roots.Adventitious shoots.Plant regeneration. Acclimation of nutrient solution

\section{Abbreviations}

$\begin{array}{ll}\text { 2,4-D } & \text { 2,4-dichlorophenoxyacetic acid } \\ \text { 6-BA } & \text { 6-benzyladenine } \\ \mathrm{GA}_{3} & \text { Gibberellic acid } \\ \text { KIN } & \text { Kinetin } \\ \text { MS } & \text { Murashige \& Skoog } \\ \text { NAA } & \text { 1-Napthyl Acetic Acid } \\ \text { ZT } & \text { Zeatin }\end{array}$

\section{Introduction}

Ipomoea batatas (L.) Lam., is a native American plant belonging to the family convolvulaceae, order polemoniales (Oggema et al. 2007) and is primarily produced in Asia, Africa and the Americas. Sweet potato is the third largest food crop in China, which accounts for $80.9 \%$ of the world production. The purple sweet potato is one of the varieties of sweet potato, and was developed in Japan in 1990s (Yang et al. 2006). Report has indicated that the anthocyanins in purple sweet potatoes displayed antioxidative or radical-scavenging activity and exerted several health-promoting functions in humans (Rabah et al. 2004). Purple sweet potatoes are less productive than ordinary sweet potatoes. The improvement of this crop by conventional hybridization is limited because of its high male sterility, incompatibility and hexaploid nature (Dhir et al.1998).Plant tissue culture and regeneration techniques are useful in the production of somaclonal variants and the development of transgenic plants are valuable tools. Transgenic genetic improvement is one of the important breeding methods of purple sweet potato. There were two pathways of plant regeneration, one was somatic embryo pathway and the other was organ regeneration pathway. The genetic improvement of purple sweet potato mainly depends on somatic embryogenesis. It was found that the somatic embryogenesis of sweet potato was genotypic limited and somatic embryogenesis took a long time (Zheng et al. 1996). Studies on the regeneration of sweet potato have predominately focused on the somatic embryogenesis method for plant regeneration (Feng et al. 2011). Up to now, sweet potato somatic embryogenesis has been documented using different explants including anthers (Tsay et al. 1979), leaves (Liu et al. 1984), meristems (Liu et al. 1984), petioles (Zheng et al.1996), buds (Sihachakr et al.1997) . However, the production of embryogenic tissues is a difficult task that requires considerable time, and high quality embryogenic tissues must be proliferated and maintained by frequent subculture without loss of their morphogenetic potential(Cheé et al.1988). In addition, production of suitable somatic embryogenic tissues is very commonly cultivar-specific and many sweet potato cultivars were found to be still recalcitrant (González et al. 2008).

Due to these difficulties, Organ regeneration pathways have been studied and was not genotypic limited and took less time. There are some reports of shoot tip culture of sweet potato (Kuo et al. 1991; Kong et al. 1998), shoot tip culture did not undergo strict cell dedifferentiation and redifferentiation, so the efficiency of genetic transformation was low. a few studies have focused on organogenesis in sweet potato regeneration with some success (Morán et al. 1998)

In general, a number of reports have been published on the regeneration of sweet potato, using various tissues from different cultivars with varying levels of reproducibility and efficiency. 
However, there is a severe limitation of genotypes for regeneration and efficiency on the whole is still relatively low (Otani et al. 2002). In addition, sweet potato is considered highly recalcitrant to regeneration and transformation and this has limited its application in genetic engineering technologies (González et al. 2008). An efficient and practicable regeneration method of sweet potato is still needed for the plant transformation to meet the requirements of effective genetic improvement of this crop. In this study, an efficient and reproducible method for the regeneration of a purple sweet potato is reported. This approach was used a segmented approach to organ differentiation which involved both organ dedifferentiation and cell redifferentiation into organs. The first paragraph, Leaf explants dedifferentiated into callus and the callus differentiated into roots. The second stage, adventitious buds were induced from adventitious roots to complete plant regeneration.

\section{Materials and methods}

I. batatas (L.) Lam cv. Ning Purple Potato No. 1, a popular variety in china, was used in this study. Potato cubes germinated at $30^{\circ} \mathrm{C}$ for 3 days, and then buds sprouted at $25 \pm 0.5^{\circ} \mathrm{C}$ for 7 days. Leaf blades were used as explants. The leaf stalks and leaves were sliced off and Explants were surface sterilized by $70 \%$ alcohol for 20secs. Then, the explants were treated with $0.1 \%$ (w/v) $\mathrm{HgCl}_{2}$ for 3-5 min under a laminar airfow chamber and washed with autoclaved double distilled water for 5 times to eliminate the excess of $\mathrm{HgCl}_{2}$. Surface-sterilized explants were cultured on MS (Murashige \& Skoog, 1962) solid medium containing $30 \mathrm{~g} \mathrm{~L}^{-1}$ sucrose and $2.6 \mathrm{~g}^{-1}$ plant gel with $0.2 \mathrm{mg} \mathrm{L}^{-1}$ to $1.0 \mathrm{mg} \mathrm{L}^{-1}$ 2, 4-D (Dessai.1995). The $\mathrm{pH}$ of the media was adjusted to 5.8 6.5 before autoclaving at $121^{\circ} \mathrm{C}$ for $20 \min (103 \mathrm{kPa})$. Leaf explants were cut into $1 \mathrm{~cm}^{2}$ discs and dedifferentiation was incubated at $25 \pm 0.5{ }^{\circ} \mathrm{C}$ in a dark growth cabinet for the first $7 \mathrm{~d}$ and then cultured with a $16 \mathrm{~h}$ photoperiod under white cool fuorescent tube light with 45-55 $\mu \mathrm{Em}^{2} \mathrm{~s}^{-1}$ Photon Flux Density.

For foot regeneration, the 50d old well-proliferated callus was transferred to the fresh MS medium containing various concentrations $\left(0.1 \mathrm{mg} \mathrm{L}^{-1}\right.$ to $\left.1.5 \mathrm{mg} \mathrm{L}^{-1}\right)$ of 6-BA, with $0.2 \mathrm{mg} \mathrm{L} \mathrm{L}^{-1}$ to $1.5 \mathrm{mg}$ $\mathrm{L}^{-1}$ NAA. The subcultures were made thirty days intervals. The number of regenerated roots were recorded after 30 days of culture.

The in vitro regenerated roots were excised to 1 to $2 \mathrm{~cm}$ long and transferred to a solid MS medium containing $800 \mathrm{mg} \mathrm{L}^{-1}$ glutamine, kinetin and zeatin at $0.5,1.0,2.0,5.0 \mathrm{mg} \mathrm{L}^{-1}$ with each level combined with $\mathrm{GA}_{3}$ at $0.0,0.5,1.0 \mathrm{mg} \mathrm{L}^{-1}$ for in vitro shooting. Finally, the in vitro regenerated plantlets were acclimatized. The plantlets were directly taken out of the culture flask and the medium adhered to the roots was washed away. The plantlets were placed in the pots containing a mixture of hoagland nutrient solution which was replenished oxygen by using oxygen pump for 10 days and then transferred to sterilized soil. The plantlets were placed in a growth chamber at $25 \pm 0.5^{\circ} \mathrm{C}$ and $80 \%$ relative humidity maintain under a cultivation chamber at $25 \pm 0.5{ }^{\circ} \mathrm{C}$ under white fuorescent tube light $\left(50 \mu \mathrm{Em}^{2} \mathrm{~s}^{-1}\right.$ Photon Flux Density) After 3 weeks. At end of the fourth week, the well-adapted plantlets were transferred to pots containing normal soil and maintained under greenhouse, then gradually transferred to the field condition.

All the experiments were repeated three times with 15 replicates, and the data were analyzed with the SPSS Software package. The mean number of roots, root length and the number of branches of the roots with the standard error were calculated after 4 week. while, the mean number of shoots were calculated after 12 week. The sample means were measured by using one-way ANOVA followed by Duncan's Multiple Range Test (DMRT) at a 5\% probability level $(\mathrm{P} \leq 0.05)$. 


\section{Results and discussion}

Callus induction was obtained from leaf explants on solid MS medium fortifed with $0.2 \mathrm{mg} \mathrm{L}^{-1}$ to $1 \mathrm{mg} \mathrm{L}^{-1}$ 2,4-D. The callus initiation was observed after 40 days of culture (Fig. 1a). Maximum rate of explants producing callus (100\%) was observed when $0.8 \sim 1.0 \mathrm{mg} \mathrm{L}^{-1}$ of 2,4-D was included in medium((Supplementary Table 1$)$. With the increase of 2,4-D concentration( $0.2 \sim 0.8$ $\mathrm{mg} \mathrm{L}^{-1}$ ), callus induction rate increased and texture changes from dense to loose. The callus color changes from light green to light yellow. The bright yellow callus was considered to have higher vigor and was easy to differentiate into embryonic callus (Belarmino et al. 1994; Liu Q C et al. 2001). The best method for callus induction was solid MS medium fortifed with $0.8 \mathrm{mg} \mathrm{L}^{-1}$ 2,4-D.

Table 1 Influence of 2,4-D on callus induction frequency of sweet potato leaf explants on solid MS medium after 6 week

\begin{tabular}{lll}
\hline $2,4-\mathrm{D}\left(\mathrm{mg} \mathrm{L}^{-1}\right)$ & $\% /$ explants producing callus & Callus texture \\
\hline 0.2 & $50 \pm 0.55^{\mathrm{d}}$ & Light green dense \\
0.4 & $85 \pm 0.25^{\mathrm{c}}$ & Light green dense \\
0.6 & $96 \pm 0.45^{\mathrm{b}}$ & Light green loose \\
0.8 & $100^{\mathrm{a}}$ & Yellowish, loose \\
1.0 & $100^{\mathrm{a}}$ & Light grey Mud shape \\
\hline
\end{tabular}

Values represent means \pm Standard Error Means followed by the same alphabets within each column are not signifcantly diferent $(\mathrm{P} \leq \mathbf{0 . 0 5})$ according to Duncan's Multiple Range Test.

Adventitious roots induction was obtained from callus on solid MS medium with $0.1 \mathrm{mg} \mathrm{L}^{-1}$ to 1.5 $\mathrm{mg} \mathrm{L}^{-1}$ 6-BA and $0.2 \mathrm{mg} \mathrm{L}^{-1}$ to $1.5 \mathrm{mg} \mathrm{L}^{-1}$ NAA. When the callus was transferred and kept growing on medium supplemented with various combinations of 6-BA and NAA for organogenesis, shoot organogenesis was not observed on media with any combination of 6-BA and NAA, but adventitious root formation did occur on medium with growth regulators. The callus on medium with 6-BA alone did not form adventitious roots, but did so on medium with NAA alone. The roots initiation was observed after 50 days of culture (Fig. 1b). Our study showed that the combination of 6-BA and NAA could induce adventitious roots from callus. Of these various concentrations tested, solid MS medium with 6-BA $0.6 \mathrm{mg} \mathrm{L}^{-1}$ and $0.3 \mathrm{mg} \mathrm{L}^{-1} \mathrm{NAA}$ produce a maximum of number of adventitious roots with numerous long and the number of branches of the roots after 4 week (Supplementary Table 2). Marilyn et al (1992) reported the leaf callus were only cultured on MS basal medium with $2.0 \mathrm{mg} \mathrm{L}^{-1} \mathrm{NAA}$ and $0.1 \mathrm{mg} \mathrm{L}^{-1} 6-\mathrm{BA}$ and could produce adventitious roots. In this study more combinations of 6-BA and NAA could induce adventitious roots were reported. Sweet potato petiole was reported with the Zeatin hormone consistently producing the most number of roots (Masekesa T R et al. 2016). Belehu et al (2004) studied preformed root primordial of the leaf bases and young leaves originated from the procambium on both sides of the leaf gap and produce adventitious roots. 


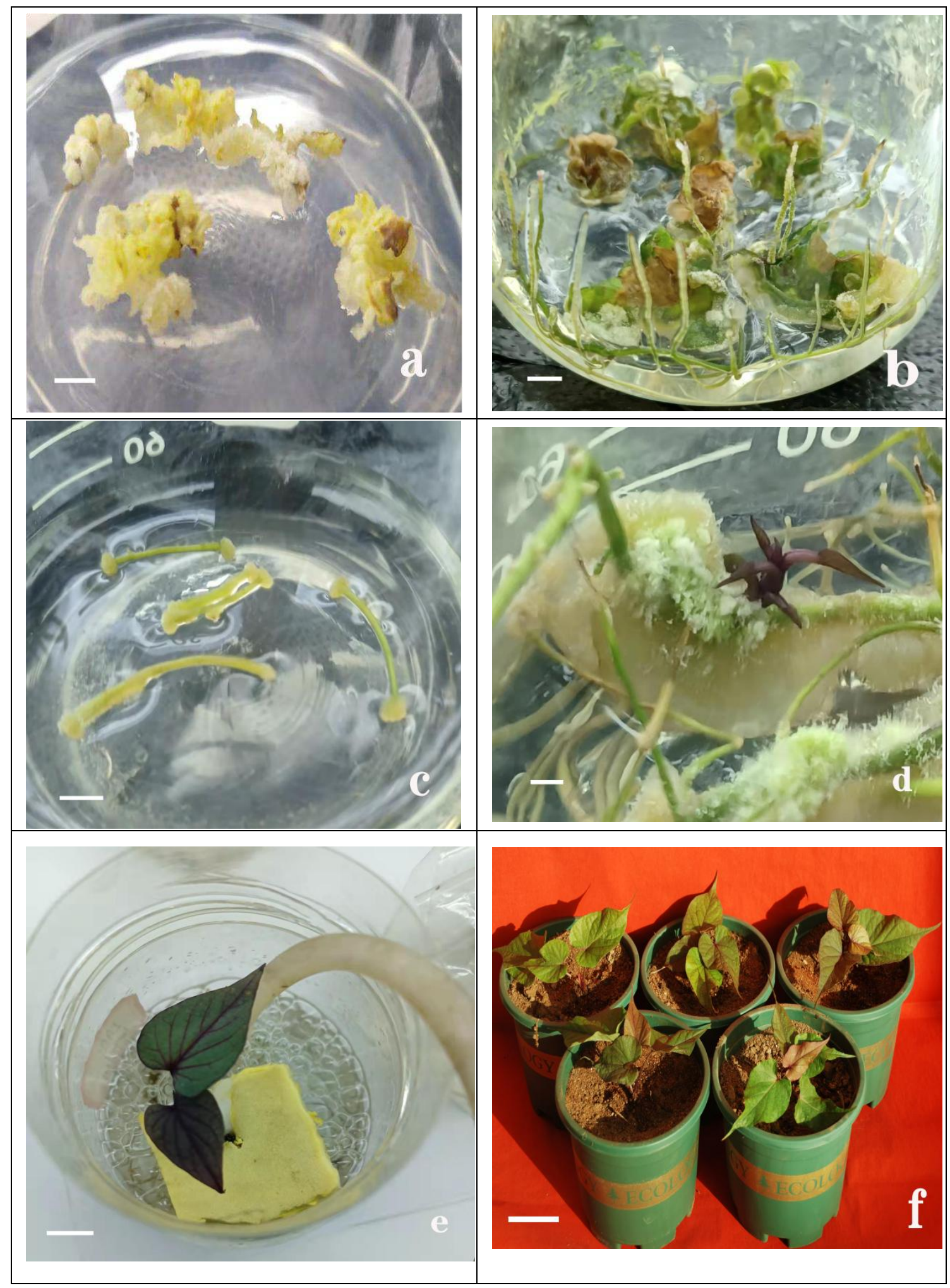

Fig. 1 In vitro callus induction and regeneration from leaf explants of Ipomoea batatas (L.) Lam. a: Callus initiation on solid Murashige and skoog (MS) medium supplemented with 2,4-D $1 \mathrm{mg} \mathrm{L}^{-1}$ after $30 \mathrm{~d}$. (Scale bar-5 mm). b: adventitious roots induction on solid MS $\mathrm{m}$ edium with 6-BA $0.6 \mathrm{mg} \mathrm{L}^{-1}$ and NAA $0.2 \mathrm{mg} \mathrm{L}^{-1}$ after 4 week (Scale bar-5 mm). C: A dventitious roots induced by callus were inoculated and cultured to induce buds on solid MS medium with ZT $2.0 \mathrm{mg} \mathrm{L}^{-1} \mathrm{KT} 1.0 \mathrm{mg} \mathrm{L}^{-1}$ and $\mathrm{GA}_{3} 1.0 \mathrm{mg} \mathrm{L}^{-1}$ after 2 week (Scale bar-5 mm). d: adventitious bud was induced from adventitious root on solid MS medium 
with ZT $2.0 \mathrm{mg} \mathrm{L}^{-1} \mathrm{KT} 1.0 \mathrm{mg} \mathrm{L}{ }^{-1}$ and $\mathrm{GA}_{3} 1.0 \mathrm{mg} \mathrm{L}^{-1}$ after 12 week(Scale bar-1 cm). e: Regenerated seedlings were acclimated in nutrient solution for 5 days $($ Scale bar-1 cm). f: Hardened plantlet transferred to pots for survival after 2 weeks (scale bar-6 cm).

Table 2 Effect of 6-BA combination with NAA on regeneration of roots from 30 days old calli of $I$. batatas (L.) Lam on solid MS medium after 8 week

\begin{tabular}{|c|c|c|c|c|}
\hline \multicolumn{2}{|c|}{ Growth Regulators $\left(\mathrm{mg} \mathrm{L}^{-1}\right)$} & \multirow{2}{*}{$\begin{array}{l}\text { Number } \\
\text { adventitious } \\
\text { roots/callus }\end{array}$} & \multirow{2}{*}{$\begin{array}{l}\text { Mean length of } \\
\text { adventitious } \\
\text { roots }(\mathrm{cm})\end{array}$} & \multirow{2}{*}{$\begin{array}{l}\text { The number of } \\
\text { branches of the } \\
\text { roots }\end{array}$} \\
\hline 6-BA & NAA & & & \\
\hline 0.1 & 0.2 & $1 \pm 1.21^{\mathrm{d}}$ & $0.5 \pm 0.27^{\mathrm{ef}}$ & $0^{\mathrm{f}}$ \\
\hline 0.5 & 0.3 & $12 \pm 0.23^{\mathrm{ab}}$ & $3.1 \pm 0.23^{b c}$ & $4 \pm 0.14^{\mathrm{c}}$ \\
\hline 0.8 & 1.0 & $2 \pm 0.25^{\mathrm{d}}$ & $1.0 \pm 0.31^{\mathrm{de}}$ & $2 \pm 0.21^{\mathrm{d}}$ \\
\hline 1.2 & 1.5 & $2 \pm 0.25^{\mathrm{d}}$ & $1.1 \pm 0.25^{\mathrm{de}}$ & $1.9 \pm 0.23^{\mathrm{de}}$ \\
\hline 0.3 & 0.3 & $10 \pm 0.25^{\mathrm{bc}}$ & $1.5 \pm 0.26^{\mathrm{d}}$ & $0^{\mathrm{f}}$ \\
\hline 0.6 & 0.3 & $15 \pm 0.16^{\mathrm{a}}$ & $4.0 \pm 031^{\mathrm{a}}$ & $8 \pm 0.25^{\mathrm{a}}$ \\
\hline 0.9 & 0.3 & $13 \pm 0.21^{\mathrm{ab}}$ & $3.8 \pm 0.26^{\mathrm{ab}}$ & $7 \pm 0.21^{\mathrm{ab}}$ \\
\hline 1.5 & 0.3 & $11 \pm 0.13^{\mathrm{bc}}$ & $3.5 \pm 0.23^{\mathrm{ab}}$ & $2 \pm 0.27^{\mathrm{d}}$ \\
\hline 0.0 & 1.0 & $0^{\mathrm{e}}$ & $0^{\mathrm{g}}$ & $0^{\mathrm{f}}$ \\
\hline 2.0 & 0.0 & $0^{\mathrm{e}}$ & $0^{\mathrm{g}}$ & $0^{\mathrm{f}}$ \\
\hline
\end{tabular}

Values represent means \pm Standard Error Means followed by the same alphabets within each column are not signifcantly diferent $(\mathrm{P} \leq \mathbf{0 . 0 5})$ according to Duncan's Multiple Range Test.

In sweetpotato, Callus induction to produce embryogenic callus and somatic embryos has been widely reported (Liu JR et al. 1984; Al-Mazrooei S et al. 1997; Dhir SK et al.1998; Liu QC et al.2001; Guo JM et al.2006; Manrique S et al. 2013). A few studies have reported on organogenesis in sweet potato shoot regeneration with some success (Morán et al.1998; Luo et al. 2006; González et al.2008) and only one adventitious root regeneration of sweet potato was reported(Marilyn et al.1992). The present study was to report the root organogenesis occurring directly from callus and more combinations of 6-BA and NAA could induce adventitious roots were reported.

Adventitious roots were transferred to solid MS medium containing various concentrations ( $0.5 \mathrm{mg} \mathrm{L}^{-1}$ to $3.0 \mathrm{mg} \mathrm{L}^{-1}$ ) of ZT, KIN with $0.5 \mathrm{mg} \mathrm{L}^{-1}$ to $2.0 \mathrm{mg} \mathrm{L}^{-1} \mathrm{GA} 3$ were used for in vitro shoot regeneration(Fig. 1c). No studies have reported on adventitious roots induced by callus were inoculated and cultured to induce buds. When the adventitious roots were sheared and transferred on medium supplemented with various combinations of ZT, KT and $\mathrm{GA}_{3}$ for the differentiation of budding, the shoots organogenesis were not observed on media with ZT, KT and GA alone. Some combinations induced buds. The shoots initiation was observed after 90 days of culture (Fig. 1d). Of these various concentrations tested, solid MS medium with ZT $2.0 \mathrm{mg} \mathrm{L}^{-1}$, KT $1.0 \mathrm{mg} \mathrm{L}^{-1}$ and $1.0 \mathrm{mg} \mathrm{L} \mathrm{LA}^{-1} \mathrm{GA}_{3}$ produce a maximum of number of adventitious shoots after 12 week (Supplementary Table 3). Belarmino et al (1994) reported that plants were regenerated from a single sweet potato callus subcultured on semi-solid MS medium containing 3\% (w/v) sucrose, $800 \mathrm{mg} \mathrm{L}^{-1}$ glutamine, $2.0 \mathrm{mg} \mathrm{L}^{-1} \mathrm{BA}$ or $1.0 \mathrm{mg} \mathrm{L}^{-1}$ kinetin and $1.0 \mathrm{mg} \mathrm{L}^{-1} \mathrm{GA}_{3}$. Up to now, the material that could induce adventitious bud of sweet potato had petiole(Gosukonda RM et al. 1995)、 leaf (Hg A K.2013)、Stem fragments(Sihachakr et al.1997; Sefasi A et al.2013)and callus(Belarmino M,1994). The present study showed that buds of adventitious roots and callus 
were obviously different and adventitious root buds first callused at both ends of the root, then adventitious buds were formed in the middle of the root. The present study was first to report the buds occurring directly from adventitious buds.

The plant regeneration process was completed when the adventitious buds were inducted from roots. When the buds reached $3 \mathrm{~cm}$ in length, they can be removed for hydroponic domestication. Adventitious roots take longer to sprout, therefore, regenerated plants should be removed from medium in time. $100 \%$ regenerated plants could be transplanted and survive after the plants had been placed in the pots containing a mixture of Hoagland nutrient solution which was replenished oxygen by using oxygen pump for 10 days(Fig. 1e). The regenerated plants were transferred into nutrient solution. The regenerated plant differentiated continuously and constantly generated new leaves. Finally, The regenerated plant could be transferred to pots containing normal soil (Fig.1f). About the domestication process, there were few detailed descriptions in the literature. if the regenerated plants were not domesticated by opening the flask to acclimatize to the environment, the regenerated plants were directly taken out of the flask and nearly $100 \%$ regenerated plants were died. The regenerated plants were transferred to containers with soil and must be maintained under high humidity and acclimatized in a mist house for two weeks (Xiansong Y et al. 2010). Finally, the survival rate of regenerated plants reached 100\% (Dessai AP et al.1995; Xiansong Y et al.2010). Controlling the gradual decline in humidity was difficult. In this paper results are presented for domestication of regenerated plants achieving nearly $100 \%$ survival of plants and taking less time without opening the flask to acclimatize to the environment and controlling the gradual decline in humidity when transferred to soil.

Table 3 Effect of ZT , KT combination with GA3 on regeneration of shoots from adventitious root of I. batatas (L.) Lam on solid MS medium after 12 week

\begin{tabular}{ccccc}
\hline ZT & Growth Regulators $\left(\mathrm{mg} \mathrm{L}^{-1}\right)$ & GA3 & $\begin{array}{c}\text { Total } \\
\text { adventitious } \\
\text { roots }\end{array}$ & $\begin{array}{c}\text { Number of buds } \\
\text { from adventitious } \\
\text { roots }\end{array}$ \\
\hline 2.0 & 0.5 & 0.5 & 30 & $1 \pm 0.23^{\mathrm{cd}}$ \\
2.0 & 1.0 & 0.5 & 30 & $5 \pm 0.21^{\mathrm{b}}$ \\
2.0 & 1.5 & 0.5 & 30 & $4 \pm 0.31^{\mathrm{bc}}$ \\
2.0 & 2.0 & 0.5 & 30 & $1 \pm 0.25^{\mathrm{cd}}$ \\
2.0 & 3.0 & 0.5 & 30 & $0^{\mathrm{e}}$ \\
2.0 & 1.0 & 1.0 & 30 & $8 \pm 0.51^{\mathrm{a}}$ \\
2.0 & 1.0 & 1.5 & 30 & $5 \pm 0.32^{\mathrm{b}}$ \\
2.0 & 1.0 & 2.0 & 30 & $0^{\mathrm{e}}$ \\
0.5 & 1.0 & 1.0 & 30 & $2 \pm 0.24^{\mathrm{c}}$ \\
1.0 & 1.0 & 1.0 & 30 & $3 \pm 0.06^{\mathrm{bc}}$ \\
1.5 & 1.0 & 1.0 & 30 & $3 \pm 0.12^{\mathrm{bc}}$ \\
3.0 & 1.0 & 1.0 & 30 & $1 \pm 0.15^{\mathrm{cd}}$ \\
2.0 & 0.0 & 0.0 & 30 & $0^{\mathrm{e}}$ \\
0.0 & 1.0 & 0.0 & 30 & $0^{\mathrm{e}}$ \\
0.0 & 0.0 & 1.0 & 30 & $0^{\mathrm{e}}$ \\
\hline
\end{tabular}

Values represent means \pm Standard Error Means followed by the same alphabets within each column are not signifcantly diferent $(\mathbf{P} \leq \mathbf{0 . 0 5})$ according to Duncan's Multiple Range Test.

\section{Conclusion}


In conclusion, a new efficient direct regeneration protocol from the leaf explants of Ipomoea batatas (L.) Lam was established. The present proposed protocol will be effective to produce a large-scale production and conservation of Ipomoea batatas (L.) Lam. The protocol was consisted of four-stage. The first stage was Callus induction of leaf explants, the second stage was adventitious roots being induced from callus, the third stage was adventitious buds being induced from adventitious roots, and the fourth stage was acclimation of nutrient solution. We had developed an efficient protocol to generate plants. As the method is simple, rapid and consistently reproducible, it may be of value in germplasm maintenance and gene transfer studies.

Acknowledgements The authors gratefully acknowledge the management of Henan Institute of Science and Technology, China for the laboratory facilities. The authors also acknowle dge the financial support of the science and technology project of Henan Provincial Depar tment of Science and Technology (Important gene regulation mechanism and new material creation of anthocyanin synthesis in sweet potato, Item no.222102110282).

Author contributions Genhai Hu designed the experiment. Genhai Hu and Xiaohong Zhang completed the collection of experimental materials and callus induction. Genhai $\mathrm{Hu}$ and Maoni Chao completed Induction of adventitious roots and shoots, Yuanzhi $\mathrm{Fu}$ completed the domestication process. All authors had written the manuscript. Genhai Hu monitored the Research. All authors read and approved the manuscript.

\section{Declarations}

Conflict of interest The authors have no conflict of interest.

\section{References}

Al-Mazrooei S, Bhatti MH, Henshaw GG, Taylor NJ(1997) Optimisation of somatic embry ogenesis in fourteen cultivars of sweet potato [Ipomoea batatas (L.) lam.]. Plant Cell Reports, 16(10):710-714. https://doi.org/10.1007/s002990050307.

Belarmino M, Abe T, Sasahara T (1994) Plant regeneration from stem and petiole protopla sts of sweet potato (Ipomoea batatas) and its wild relative, i. lacunosa. Plant Cell Tis sue \& Organ Culture, 37(2):145-150. https://doi.org/10.1007/BF00043608

Belehu T, Hammes PS, Robbertse PJ (2004) The origin and structure of adventitious roots in sweet potato (Ipomoea batatas). Australian Journal of Botany 52:551-558. https://d oi.org/10.1071/BT03152

Cheé RP, Cantliffe DJ (1988) Selective enhancement of Ipomoea batatas Pior. embryogenic and non-embryogenic callus growth and production of embryos in liquid culture. Plant Cell Tissue Organ. Cult. 15:149-159. https://doi.org/10.1007/BF00035756

Dessai AP, Gosukonda RM, Blay E(1995) Plant regeneration of sweetpotato (Ipomoea bata tas L.) from leaf explants in vitro using a two-stage protocol. Sci. Hortic. 62:217-224. https://doi.org/10.1016/0304-4238(95)00767-N

Dhir SK, Oglesby J, Bhagsari AS(1998) Plant regeneration via embryogenesis and transient gene expression in sweet potato protoplasts. Plant Cell Rep 17:665-669. http://dx.doi. org/10.1007/s002990050462

Feng C, Yin Z, Ma Y et al (2011) Cryopreservation of sweetpotato (Ipomoea batatas) and its pathogen eradication by cryotherapy. Biotechnol. Adv. 29:84-93. https://doi.org/10. 1016/j.biotechadv.2010.09.002

Guo JM, Liu QC, Zhai H(2006) Regeneration of plants from ipomoea cairica 1. protoplasts 
and production of somatic hybrids between I. cairica 1. and sweetpotato, I. batatas (L.) lam. Plant Cell Tissue \& Organ Culture, 87(3):321-327. https://doi.org/10.1007/s11 240-006-9135-x

González RG, Sánchez DS, Guerra ZZ, et al (2008) Efficient regeneration and Agrobacterium tumefaciens mediated transformation of recalcitrant sweet potato (Ipomoea batatas L.) cultivars. Asia Pac. J. Mol. Biol. Biotechnol. 16:25-33. https://doi.org/10.1.1.511.2031\&rep

Gosukonda RM, Porobodessai A, Blay E, et al (1995) Thidiazuron-induced advetitious shoot regeneration of sweetpotato (Ipomoea batatas). in vitro cell devel. biol. 31:65-7 1. In Vitro Cellular \& Developmental Biology - Plant, 31(2):65-71. https://doi.org/10.1 007/BF02632239

Hg AK (2013) Protuberance-mediated high frequency of adventitious shoot regeneration from sweetpotato leaf explants [Ipomoea batatas (L.) lam.]. Biotechnologia, 94(4):445-450. https://doi.org/10.5114/bta.2013.46414

Kong XS, Zhang MX, Guo XP (1998) Studies on tip meristem culture and rapid propagation techniques sweet potato. Acta Agriculturae Universitatis Henanensis, 32(2):133-137. https://doi.org/CNKI:SUN:NNXB.0.1998-02-005

Kuo CG, Shen BJ, Shen MJ(1991) Virus-free sweet potato storage roots derived from meristem-tips and leaf-cuttings. Scientia Horticulturae, 26(3):231-240. https://doi.org/ $10.1016 / 0304-4238(85) 90110-4$

Liu QC, Zhai H, Zhang Y (2001) Efficient plant regeneration from embryogenic suspension cultures of sweetpotato. Vitro Cellular \& Developmental Biology Plant, 37(5):564-567. https://doi.org/10.2307/4293513.

Liu JR, Cantliffe DJ(1984) Somatic embryogenesis and plant regeneration in tissue cultures of sweet potato (Ipomea batatas poir.). Plant Cell Reports, 3(3):112-115. https://doi.or $\mathrm{g} / 10.1007 / \mathrm{BF} 02441013$

Luo HR, Santa MM, Benavides J et al (2006) Rapid genetic transformation of sweetpotato (Ipomoea batatas (L.) Lam) via organogenesis. Afr. J. Biotechnol. 5:1851-1857. https: //doi.org/10.5897/AJB2006.000-5074

Masekesa TR, Gasura E, Ngadze E (2016) Efficacy of zeatin, kinetin and thidiazuron in induction of adventitious root and shoot from petiole explants of sweetpotato cv. brondal. South African Journal of Botany, 104: 1-5. https://doi.org/ 10.1016/j.sajb.2015.11.001.

Marilyn MB, Toshinori A, Takeo S (1992) Efficient plant regeneration from leaf calli of I pomoea batatas(L.) Lam and its related species. Japan.J.breed.42:109-114. https://doi.or $\mathrm{g} / 10.1270 / \mathrm{jsbbs} 1951.42 .109$

Manrique S, Díaz D, Reaño R, Ghislain M, Kreuze J(2013) Sweetpotato plant regeneration via an improved somatic embryogenesis protocol. entia Horticulturae, 161(2): 95-100. https://doi.org/10.1016/j.scienta.2013.06.038.

Morán R, García R, López A et al (1998) Transgenic sweet potato plants carrying the del ta-endotoxin gene from Bacillus thuringiensis var. tenebrionis. Plant Sci. 139:175-184. http://dx.doi.org/10.1016/S0168-9452(98)00179-4.

Morán R, García R, López A (1998) Transgenic sweet potato plants carrying the delta-end otoxin gene from Bacillus thuringiensis var. tenebrionis. Plant Sci. 139:175-184. https:/ /doi.org/10.1128/AAC.01107-07

Oggema JN, Kinyua MG, Ouma JP et al (2007) Agronomic performance of locally adapted sweet 
potato (Ipomoea batatas (L.) Lam.) cultivars derived from tissue culture regenerated plants. African J Biotech 6(12): 1418-1425. https://doi.org/10.1186/1471-2180-7-57

Otani M, Shimada T (2002) Transgenic sweet potato with agronomically important genes. In Khachatourians G, Mchughen A, Scorza R, Nip WK, Hui YH (eds), Transgenic Plant and Crops, New York, Marcel Dekker pp. 699-716.

Rabah IO, Hou DX, Komine SI et al (2004) Potential chemopreventive properties of extract from baked sweet potato (Ipomoea batatas Lam. Cv. Koganesengan). J. Agric. Food Chem., 23: 7152-7157. https://doi.org/ 10.1021/jf049368w

Sihachakr D, Haicour R, Cavalcante JM (1997) Plant regeneration in sweet potato (Ipomoe a batatas L., Convolvulaceae). Euphytica 96:143-152. https://doi.org/10.1023/A:1002997 319342

Sefasi A, Ghislain M, Kiggundu A(2013) Thidiazuron improves adventitious bud and shoot regeneration in recalcitrant sweetpotato. African Crop Science Journal, 21(1): 85-95. https://doi.org/10.4314/acsj.v21i1.

Tsay HS, Tseng MT (1979) Embryoid formation and plantlet regeneration from anther callus of sweet potato. Botanical bulletin of Academia Sinica. New series, 20(2): 117-122. https://doi.org/10.1515/botm.1979.22.8.539

Xiansong Y(2010) Rapid production of virus-free plantlets by shoot tip culture in vitro of purple-coloured sweet potato (Ipomoea batatas (L.) lam.). Pakistan Journal of Botany, 42(3): 2069-2075. https://doi.org/10.1246/bcsj.81.369

Xiansong Y, ZhanmiaoY, Feng G(2006)Advances in anthocyanin pigments from purplesweet potato. Chinese Agric. Sci. Bulletin, 22(4): 94-98. https://doi.org/ 10.3969/j.issn.10006850.2006.04.024

Zheng Q, Porobo DA, Prakash CS (1996) Rapid and repetitive plant regeneration in sweet potato via somatic embryogenesis. Plant Cell Reports 15(6):381-385. https://doi.org/1 $0.1007 / \mathrm{BF} 00232059$ 